\title{
Human Capital Outsourcing Services and Corporate Performance of Manufacturing Companies in Port Harcourt, Rivers State
}

\author{
George Yebimodei Esther, Odubo Angonimi, Sani Abubakar
}

\begin{abstract}
This study examined the association between Human Capital Outsourcing Services and Corporate Performance of Manufacturing Companies in Port Harcourt, Rivers State. The research adopted a correlational cross-sectional survey design. A total of seventy-five respondents were drawn from existing managerial employees across the twenty five (25) Manufacturing Companies in Port Harcourt. The researcher collected data on a macro level unit of analysis using a five-point Likert Scale. Pearson Product Moment Correlation Coefficient (PPMCC) was used for hypotheses testing. These analyses were conducted using a computer software package called the Statistical Package for Social Sciences (SPSS) version 20.0. The result of the findings revealed that outsourcing human resource services gives rise to corporate profitability and improved market share respectively. Based on empirical findings, the researcher then concluded that outsourcing Human Resource Services significantly and positively affects corporate performance of manufacturing companies in Port Harcourt. The researcher therefore recommended that: Manufacturing Companies in Port Harcourt should stimulate human resource outsourcing in order to achieve profitability and high sales volume.

Index Terms - Human Capital Outsourcing Services,
\end{abstract} Corporate Performance, Profitability, Market Share.

\section{INTRODUCTION}

The current economic down-turn in Nigeria is changing business dynamics and operational models. Restructuring or right-sizing by business organizations is becoming the order of the day. A common denominator in restructuring is the identification and separation of core from non-core activities. Subsequently, processes are built around both activities to support overall enterprise goals (Uwadiae, 2017). To achieve a functional, efficient and cost-effective organization, it is now common knowledge that certain processes are better outsourced to a service provider than managed internally. Outsourcing jobs in Nigeria has become a subject of greater concern as more employees continue to groan under the 'policy of wages reduction' by the employers of labour without compromising the quality of services provided. In almost all the sectors of the Nigerian economy, outsourcing of staff has become the norm as employers find the system most congenial for their businesses, and therefore are no

George Yebimodei Esther, Department of Business Administration, School of Management Sciences Federal Polytechnic, Ekowe, Bayelsa State Odubo Angonimi, Department of Marketing, School of Management Sciences Federal Polytechnic, Ekowe, Bayelsa State

Sani Abubakar, Department of Business Administration, School of Management Sciences Federal Polytechnic, Ekowe, Bayelsa State longer bargaining for employees with a permanent status at the workplace. Human Capital or Resource Outsourcing is 'a process of replacement of in-house provided activities by subcontracting them out to external agents for cost- benefit and exigency purposes' (Irefin, Olateju, \& Hammed). It is a system in which organizations give out some of its services to outside services providers to handle on their behalf. Outsourcing of human resources has come a long way in history, and has continued to be more acceptable in Nigeria and other developing nations of the world. Most of the organizations engaging in outsourcing are situated in the urban areas where population and skilled and unskilled labours are densely concentrated.

Howbeit, despite the world-wide practice of outsourcing by organizations, many companies are et to fully understand and tap into the numerous benefits of outsourcing. In addition, outsourcing helps to achieve sustainable efficient corporate performance thereby increasing revenue bases, enhancing quality service delivery to customers, reducing exposures to business risks, increasing manpower efficiency and optimizing product-line processes etc. with the current economic situation, the dream of every management is to operate at maximum efficiency and at the lowest possible cost without hurting bottom line. Outsourcing services help companies to access specialized services that can increase revenue and reduce operating costs. Outsourcing gives access to the best expertise in the relevant field without incurring costs of maintaining such expertise within the organization. Organizations tend to protect their profitability by diversifying; and to improve flexibility and creativity, most companies establish strategic decisions to focus on the firm's core business in order to identify processes that are critical to making outsourcing decisions.

Despite the growing trends of logistics outsourcing, there are very limited sources of literature on outsourcing practices in Nigeria. Suffice it to mention that there are limited studies on outsourcing. Hence, it is crucial in the Nigerian context to understand the extent of outsourcing practices in this country and the relevant models. In this study, an evaluation was made over the relationship between human resource outsourcing services and corporate performance of Manufacturing Companies in Port Harcourt. The study was guided by the following research questions:

i. What is the relationship between Human Capital Outsourcing Services and Profitability of Manufacturing Firms in Port Harcourt? 


\section{Rivers State}

ii. What is the relationship between Human Capital Outsourcing Services and market share of manufacturing companies in Port Harcourt?

\section{LITERATURE REVIEW}

\section{Theoretical Foundation}

The underpinning theory for this study is the Resource-based view (RBV). Discussions on the RBV of firms began with Wernefelt (1984), who espoused the Resource-based view of firms by analuzing firms from the resource perspective in contrast to other aspects. Barney (1991), then proposed the RBV framework to study a firm's internal strengths and weaknesses. The important assumptions of the RBV are heterogeneity and immobility in which case, a firm's resources are presumed to be controlled by a firm to allow it to be able to execute business strategies to boost its performance. Since then, scholars have discussed boundary choices, core competencies, and competitive advantages from the firm's resources perspective. Hsiao et al (2010) identified two main determinants for outsourcing: core competencies and the value of human assets for specific business activities.

According to Dekkers (2011), and Wernefelt (1984), the RBV defined resources as tangible and intangible assets that are rooted half-permanent to a firm. Barney (1991), however moved the emphasis from the organizational view to the firm's goal of reducing the uncertainty and dependency on other organizations to reduce the risk for its survival. Ettlie and Sethuraman (2002) strongly related the RBV to outsourcing, while Holcomb and Hitt (2007) combined the RBV with TCT to arrive at a proposition for outsourcing. This is supported by McIvor et al (2008), who combined the same theories for his case studies analysis in outsourcing. Outsourcing has been investigated from different perspectives due to its multidisciplinary nature, in which the transaction cost view and resource-based view are the major approaches that have been used (Hsaio et al., 2010).

\section{Human Capital Services}

Human Capital or Resource Outsourcing services support systems responsible for personnel sourcing and hiring, applicant tracking, skills development and tracking, benefits administration and compliance with associated government regulations (Poppo\& Zenger, 1999). The role of human resource outsourcing services provision is to plan, organize, manage, and administer the personnel system including pay roll, benefits, classification, compensation, recruitment, selection, safety, employer/labour relations, discipline, grievances, appeals, records, personnel rules and policies (Moncarz et al., 2008). The human resource service provides direction and technical assistance in these functional areas to managers, supervisors and employees through personnel rules, policies, programmes, direct consultation and advice.

The Human Resource Department is a critical component of employees' wellbeing in any business, no matter how small. Some businesses often don't have the staff or the budget to properly handle the nitty-gritty of Human Capital Management. Because of this, more and more businesses are beginning to outsource their Human Resource needs. Human Resource outsourcing services generally fall into four categories: PEOs, BPOs, ASPs or E-services 9Moncarz et al. 2008).

Professional Employer Organization (PEO) In this situation, the service provider assumes full responsibility of the company's HR administration (Moncarz et al., 2008). The service provider becomes a c0-employer of the client's company's workers by taking full legal responsibility of the employees, including having the final say in hiring, firing, and the amount of money employees make. The PEO and business owner become partners, essentially with the PEO handling all the HR aspects and the business owner handling all other areas of the company's concerns (Whitaker, Krishnan, \&Fornell, 2008). By proper definition, a ssrvice is only a PEO wnen it takes legal responsibility for employees. But it should be noted that some HR outsourcing services like to use the recognized term:"PEO" when handling the primary aspects of HR roles such as payroll and benefits.

\section{Business Process Outsourcing (BPO)}

Business Process Outsourcing is a broad term referring to outsourcing in all fields, not just Human Resource. A BPO differentiates itself by either putting in new technology or applying existing technology in a new way to improve a process. Specifically in HR, a BPO would make sure a company's HR system is supported by latest technologies, such as self-access and HR data warehousing (Whitaker, Krishnan, \&Fornell, 2008).

\section{Application Service Providers (ASPs)}

Application service providers host software on the web and rent it to users. Some are well-known packaged applications (People Soft), while others are customized HR software developed by the vendor. These software programs can manage payroll, benefits and more.

\section{E-Services}

E-Services are those HR services that are web-based. Both BPOs and ASPs are often referred to as e-services. The key to hiring the right outsourcing firm knows what services your company needs and then finds an outsourcing firm that provide them. When outsourcing HR functions, some services go with the "all-or-nothing" approach, requiring that they handle all the business owner's HR functions or none at all (Poppo\& Zenger, 1999). Others offer their services " a la carte", meaning you can pick and choose from the services they offer. Typical services according to Poppo and ZENGER (1999) include: (i) Payroll Administration: including signing of cheques, handling tax matters, and dealing with sick time and vacation time. (ii) Employee Benefits: including health medicals and life insurance plans and cafeteria plans. (iii) Human Resource Management: including hiring and firing. This also involves background interviews, exit interviews and wage reviews. (iv) Risk Management: including workers' compensation, dispute resolution, safety inspection, office policies and handbooks. Some services are full service and will provide those as well as additional services like on-call consultants who will come to train or even settle a dispute.

\section{Corporate Performance}

Corporate performance is the final achievement of an organization and contains a few things, such as the existence of achieved targets, has a period of time in achieving the 
targets and the realization of efficiency and effectiveness (Gibson et al., 2010). On the other hand, organizational performance refers to the ability of an enterprise to achieve such objectives as high profit, quality products, large market share, good financial results, and survival at pre-determined time using relevant strategy for action (Koontz \& Donnell, 2003). Organizational performance can also be used to view how an enterprise is doing in terms of level of profit, market share, and product quality in relation to other enterprises in the same industry. Consequently, it is a reflection of productivity of members of an enterprise measured in terms of revenue, profit, growth, development, and expansion of the organization. All types of organizations whether small or big, public or private, for-profit, or not-for-profit, struggle for survival. In order to survive, they need to be successful (effective and efficient). To assure their success, organizations must perform well.

Ultimately, performance lies at the heart of any managerial process and organizational construct; and is therefore considered as a critical concept in the strategic management field. Organizational performance includes multiple $=\mathrm{e}$ activities that help in establishing the goals of the organization, and monitor the progress towards the target (Johnson et al., 2006). It is used to make adjustments to accomplish goals more efficiently and effectively. Corporate performance is what business executives and owners are usually frustrated about. This is so because, even though the employees of the company are hard-working and are busy doing their tasks, their organizations are unable to achieve the planned results. However, for any business to be successful, functions must be defined and accomplished. It is important for an organization to develop strategies that are designed around the skills that would enhance the performance of the enterprise.

\section{Measures of Corporate Performance}

Different measures of corporate performance exist. The ones highlighted are a function of the corporate performance that is under investigation. For the purpose of this study, the measures are: Profitability and Market Share.

\section{Profitability:}

Profitability refers to money that a firm can produce with the resources it has. The goal of most organizations is profit maximization (Niresh\&Velnampy, 2016). Profitability involves the capacity to make benefits from all the business operations of an organization, firm or company (Muya\&Gathogo, 2016). Profit usually acts as the entrepreneur's reward for investment. As a matter of fact, profit is the main motivator of an entrepreneur for doing business. Profit is also used as an index for the performance measurement of a business (Ogbadu, 2009). Profit is the difference between revenue received from sales and total costs which include material costs, labour, and so on (Stiewald, 2010). Profitability can be expressed either as accounting profits or economic profits and it is the main goal of a business venture (Anene, 2014). Profitability portrays the efficiency of the management in converting the firm's resources to profits (Muya\&Gathogo, 2016). Thus, firms are likely to gain a lot of benefits related to increased profitability (Niresh\&Velnampy, 2014). One important precondition for any long-term survival and success of a firm is profitability. It is profitability that attracts investors and the business is likely to survive for a long period of time (Farah \& Nina, 2016). Many firms strive to improve their profitability and they do spend countless hours in meetings trying to come uo with a strategy to reduce operating costs as well as on how to increase their sales (Schreibfeder, 2006).

\section{Market Share}

Market share refers to the percentage of sales a company has in a specific market within a specific time period. Higher market share translates higher profits. Gaining or building market share is an offensive or attack strategy to improve the company's standing in the market (Srkissian, 2010). Market share is a measure of the consumers' preference for a product over other similar products. A higher market share usually means greater sales, lesser efforts to sell more and a strong barrier to entry for other competitors. A higher market share also means that if the market expands, the leader gains more than the others. By the same token, a market leader- as defined by its market share also has to expand the market for its own growth (Schnaars, 1998).

There are many different ways to increase market share,; companies usually use a combination of strategies. Sometimes something as basic as increasing advertising can have a huge effect, as can adjusting pricing. Breaking products into groups and targeting them at specific demographics can also increase this percentage, as can the making of complimentary products.

Relationship between Human Capital Outsourcing Services and Corporate Performance

Zailani et al (2015), examines the relationship between factors influencing outsourcing and the extent of logistics outsourcing practices. The results of the study provide support that superior performance is correlated to the resources of the firm. The analysis further shows that lack of human and physical asset capabilities, as well as transaction uncertainty influence the extent of different logistics outsourcing practices. Although theoretically, firms aim at cost reduction by employing a logistics outsourcing strategy, but not proven in the study because the financial benefit was only positively contributed by one of the four logistics outsourcing practices under study. Besides that, the results from the study also support that most firms outsource their non-core activities of the logistics practices to respond to the transaction uncertainty that may be present in their business experiences. Kang et al., (2014), empirically examine the relationships among outsourcing strategies and organizational control in the Chinese context and refine the theoretical and managerial implications. Findings suggest that for efficiency-seeking outsourcing, output control and process control are appropriate in creating successful outsourcing practices. Mwelu et al (2015), establish whether the outsourcing practice has any impact on the profitability level of manufacturing firms in Uganda. Findings indicated that outsourcing has a positive significant association with the level of profitability of manufacturing firms in Uganda. The findings further indicated that whereas there is a strong and significant association between outsourcing and profitability, outsourcing is not yet pronounced enough to 
cause significant influence onto the profitability levels of manufacturing firms in Uganda.

Min (2013) examines the common logistics outsourcing practices among the US firms and identifies key determinants influencing their logistics outsourcing decisions. It also explores the current logistics outsourcing trends in terms of customer value proposition. He discovered that most frequently outsourced logistics services are those that are related to global logistics operations. These include customs clearance/brokerage, port services, and import/export documentation. The study revealed synonymous congruence with earlier studies conducted by Min, (2013) and Lagley and Capgemini (2013), more transactional, operational, and routine logistics services such as freight bill audit and payment and freight forwarding are frequently outsourced. On the other hand, logistics activities which may deal with more confidential information such as demand forecasting/planning, are seldom outsourced. Also, frontline services that require more direct contact with end customers such as customer relationship management (CRM) are rarely outsourced.

The foregoing argument gave rise to the following hypotheses:

Ho: There is no significant relationship between Human Capital Outsourcing Services and profitability of manufacturing firms in Port Harcourt.

$\mathbf{H o}_{2}$ : There is no significant relationship between Human Capital Outsourcing Services and market share of manufacturing firms in Port Harcourt.

\section{METHODOLOGY}

The cross-sectional survey research design which is correlational in nature was applied in this study. Therefore, the target population constitutes a total of twenty-five (25) manufacturing companies that are registered with the Manufacturing Association of Nigeria (MAN), Port Harcourt, Rivers State. Considering the number of these registered companies, the researcher studied all the manufacturing companies hence these twenty-five (25) registered companies also formed the researcher's accessible population. To determine the sample size for this study, and since the researcher chose to study all the subjects in the population, the researcher therefore adopted a convenience sample procedure to sample only the management staff of the companies.

These are senior, intermediate and supervisory managers in each of the selected manufacturing companies in Port Harcourt.

The reason was that this category of staff would be in more vantage positions to give accurate information on the practice of outsourcing in their respective organizations. Therefore, three (3) questionnaire copies were distributed to each of the twenty-five (25) manufacturing companies in Port Harcourt which gave a total of seventy-five (75) questionnaire copies to be distributed. Out of this 75 copies, 70 were properly filled and returned; which then formed our sample size. Descriptive statistics and Spearman's Rank Order Correlation was used for data analysis and hypotheses testing.

Table 1: Reliability for Outsourcing Practices Dimension and Corporate Performance.

\begin{tabular}{lcc}
\hline \multicolumn{1}{c}{ Variables } & Indicators & Cronbach Alpha Coefficient \\
\hline HC Services & 5 & 0.630 \\
Profitability & 5 & 0.968 \\
Market Share & 5 & 0.871 \\
\hline
\end{tabular}

Source: SPSS Data Output, 2020

\section{DATA ANALYSIS AND RESUL}

\section{Bivariate Analysis}

The secondary analysis from the results of the hypotheses were presented with tests conducted using the Spearman's Rank Order Correlation Coefficient at 95\% confidence level which was adopted as a criterion for the probability for either accepting the null hypotheses at $(\mathrm{p}>0.05)$ or rejecting the null hypotheses formulated at $(\mathrm{p}<0.05)$. in clear terms, the test covers the six hypotheses postulated for the study (ie. $\mathrm{Ho}_{1}$ and $\mathrm{Ho}_{3}$ ) which were bivariate in natire and stated in the null form.

\section{Test of Hypothesis One}

$\mathrm{Ho}_{1}$ : There is no significant relationship between Human Capital Outsourcing Services and Probability of manufacturing firms in Port Harcourt.

Table 2: Correlation Result for Human Capital Outsourcing Services and Profitability.

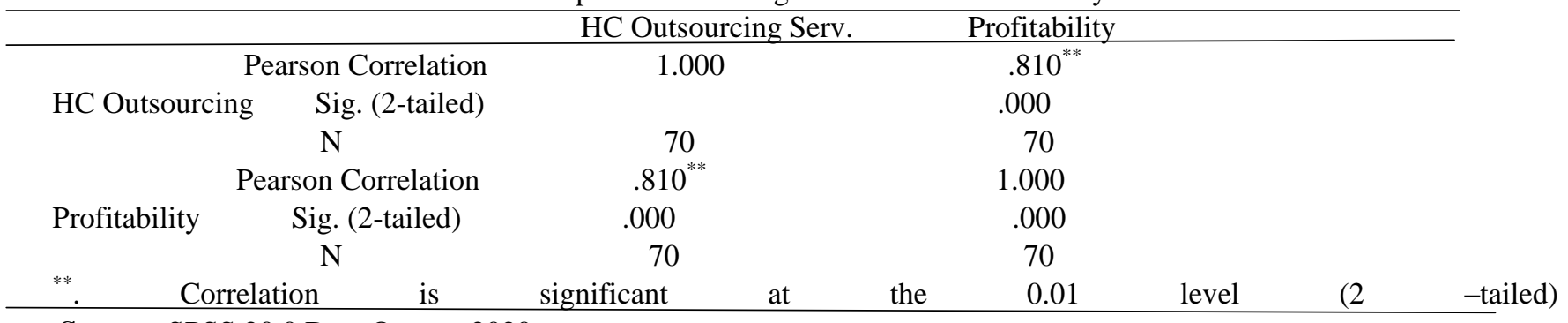

Source: SPSS 20.0 Data Output, 2020.

From the result in table 2, it was shown that a significant and high positive linear relationship exists between Human Capital Outsourcing Services and Profitability. The (p) value of .810 indicates that the association is significant at $\mathrm{p}=$
$0.000<0.01$ level of significance. The $\mathrm{r}$ coefficient shows a very high correlation indicative of a very strong relationship. Therefore, the stated null hypothesis was rejected and the alternate hypothesis upheld; meaning that there is a 
significant relation between Human Capital Outsourcing Services and Profitability of Manufacturing Companies in Port Harcourt.

\section{Test of Hypothesis Two}

$\mathrm{Ho}_{2}$ : There is no significant relationship between Human Capital Outsourcing Services and Market Share of Manufacturing Companies in Port Harcourt.

Table 3:Correlation Result for Human Capital Outsourcing Services and Market Share.

\begin{tabular}{llcc}
\hline & & HC Outsourcing Serv. & Market Share \\
\hline \multirow{4}{*}{ HC Outsourcing } & Pearson Correlation & 1.000 & $.591^{* *}$ \\
& Sig. (2-tailed) & & .000 \\
& $\mathrm{~N}$ & 70 & 70 \\
\multirow{4}{*}{ Market Share } & Pearson Correlation & .591 & 1.000 \\
& Sig. (2-tailed) & .000 &. \\
$*$ ** Correlation is significant at the 0.01 level (2-tailed). & 70
\end{tabular}

Source: SPSS 20.0 Data Output, 2020.

From the result in table 3 above, it was shown that a significant and positive linear relationship exists between Human Capital Outsourcing Services and Market Share. The (p) value of .591 indicates that the association was significant at $\mathrm{p}=0.000<0.01$ level of significance. The $\mathrm{r}$ coefficient revealed a moderate correlation indicative of a moderate relationship. Therefore, the stated null hypothesis was rejected and the alternate hypothesis upheld; meaning that there is a significant relationship between Human Capital Outsourcing Services and Market Share of Manufacturing Companies in Port Harcourt.

\section{DISCUSSION OF FINDINGS}

The study revealed that there is a significant positive relationship between Human Capital Outsourcing Services and Corporate Performance of Manufacturing Companies in Port Harcourt. This outcome contradicts the findings of Mwelu et al (2014), in their study conducted to establish whether outsourcing practices had any impact on the profitability level of manufacturing firms in Uganda. Findings from this study indicated that outsourcing has a positive significant association with the level of profitability of manufacturing companies in Uganda. The findings further indicated that whereas there is a strong and significant association between Human Capital Outsourcing Services and profitability, outsourcing is not very pronounced enough to cause significant influence on the profitability levels of manufacturing firms in Uganda.

This result collaborates with the view of Rao and Young (1994): the centrality of the logistics function, risk control, cost trade-offs, information technologies and relationship with service providers are among the criteria and supported by the view of Damme and Amstel (1996) as they stated that another four categories of consideration in Human Capital Outsourcing logistics functions are economic viability, market issues, resources availability, and the extent of supplier dependence.

\section{CONCLUSION AND RECOMMENDATIONS}

Based on the results from data analysis, and findings of the research; it could be concluded that there is a significant relationship between Human Capital Outsourcing Services and Corporate Performance.

Drawing from the foregoing, the following recommendations were proffered:
1. Manufacturing Companies in Port Harcourt should stimulate Human Capital Outsourcing Services in order to achieve profitability.

2. Manufacturing Companies in Port Harcourt should encourage Human Capital Outsourcing Services in order to ensure increased market share.

\section{REFERENCES}

[1] Anene, E. C. (2014). What difference does inventory control make in typical small scale farms' profitability? Journal of Management, Sciences and Business Research, 3(10), 1-4.

[2] Barney, J., (1991). Firm resources and sustained competitive advantage. Journal of Management, 17(1), 99-120.

[3] Damme, D.A.V., \& Amstel, M. J., (1996). Outsourcing logistics management activities. Int. Journal of Logist. Management, 7 (2), 85-95.

[4] Dekkers, R., (2011). Impact of strategic decision-making for outsourcing on managing manufacturing. Int. journal of Production Management, 31 (9), 935-965.

[5] Ettlie, J.E. \&Sethuraman, K., (2002). Locus of supply and global manufacturing. International Journal of Operations Production Management, 22 (3), 349-370.

[6] Farah, M. \& Nina, S., (2016). Factors affecting profitability of small medium enterprises (SMEs) firms listed on the Indonesian Stock Exchange. Journal of Economics, Business and Management, 4 (2), 132-137.

[7] Holcomb, T. R., Hitt, M. A., (2007). Towards a model of strategic outsourcing. Journal of Operations Management, 25 (2), 464-481.

[8] Hsiao, H. I., Vander, Vorst JGAJ, Kemp RGM, \&Omta SWF, (2010). Developing a decision-making framework for levels of logistics outsourcing in food supply chain networks. International Journal of Physical Distribution Logistics Management, 40 (5), 395-414.

[9] Irefin, I. A., Olateju, O. I. \& Hammed, G.O. (2012). Effect of outsourcing strategy on project success. Transnational Journal OF Science and Technology, 2 (6), 128-143.

[10] Langley, J., Newton, B.f. \& Tyndall, G. R., (1999). Has the future of third party logistics already arrived? Supply Chain Management Review, 33, 85-94.

[11] McIvor, R., Humphreys, P., Wsll, P. \&McKittick, A., (2008). A study of performance measurements in the outsourcing decision. Res Exec SummSer, 4 (3), 1-13 MIDA (2011).

[12] MIN, H., (2013). Examining logistics outsourcing practices in the United States: from the perspectives of third-party logistics service users. Logist Res. 6 (4), 133-144.

[13] MUYA, T. W. \&Gathogo, G., (2016). Effect of working capital management on the profitability of manufacturing firms in Nakuru Town, Kenya. International Journal of Economics, Commerce and Management, 1 (4), 1082-1105.

[14] Niresh, J. A. \&Velnampy, T,. (2014). Firm size and profitability: A study of listed manufacturing firms in Sri Lanka. International Journal of Business and management, 9, 57-64.

[15] Ogbadu, E.E., (2009). Profitability through effective management of materials. Journal of Economics and International Finance, 1 (4), 99-105.

[16] Poppo, L., \& Zenger, T., (1998). Testing alternative theories of the firm: transaction cost, knowledge-based, and measurement explanations for make-or-buy decisions in information services. Strategic Management Journal, 19 (9), 853-877. 
Human Capital Outsourcing Services and Corporate Performance of Manufacturing Companies in Port Harcourt, Rivers State

[17] Rao, K., Young, R., (1994). Global supply chains: factors influencing outsourcing of logistics functions. International Journal of Physical Distribution Logistics Management, 24 (6), 11-19.

[18] Schnaars, S. P., (1994). Managing imitation strategies: How late entrants seize marketing from pioneers. New York: The Free Press.

[19] Schreibfeder, J., (2006). Inventory management: Analyzing inventory to maximize profitability. Effective Inventory Management, Inc.

[20] Stierwald, A., (2010). Determinants of profitability: An analysis of large Australian firms. Mebourne Institute Working Paper.

[21] Zailani, S., Iranmanesh, M,.Nikbin, D. \&Beng, J.K.C., (2015) Determinants of RFID adoption in Malaysia's healthcare industry: occupation level as a moderator. Journal of Medical Systems, 39 (1), $1-11$

[22] Zailani, S., Govindan, K., Iranmanesh, M. \&Shaharudin, M.R., (2015). Green innovation adoption in automotive supply chain: the Malaysian case. Journal of Clean Production. 